\title{
Transgenic mouse models for ADHD
}

\author{
Damiana Leo $\cdot$ Raul R. Gainetdinov
}

Received: 19 February 2013 / Accepted: 15 April 2013 / Published online: 17 May 2013

(C) The Author(s) 2013. This article is published with open access at Springerlink.com

\begin{abstract}
Attention-deficit hyperactivity disorder (ADHD) is a developmental disorder characterized by symptoms of inattention, impulsivity and hyperactivity that adversely affect many aspects of life. Whereas the etiology of ADHD remains unknown, growing evidence indicates a genetic involvement in the development of this disorder. The brain circuits associated with ADHD are rich in monoamines, which are involved in the mechanism of action of psychostimulants and other medications used to treat this disorder. Dopamine (DA) is believed to play a major role in ADHD but other neurotransmitters are certainly also involved. Genetically modified mice have become an indispensable tool used to analyze the contribution of genetic factors in the pathogenesis of human disorders. Although rodent models cannot fully recapitulate complex human psychiatric disorders such as ADHD, transgenic mice offer an opportunity to directly investigate in vivo the specific roles of novel candidate genes identified in ADHD patients. Several knock-out and transgenic mouse models have been proposed as ADHD models, mostly based on targeting genes involved in DA transmission, including the gene encoding the dopamine transporter (DATl). These mutant models provided an opportunity to evaluate the contribution of dopamine-related processes to brain pathology, to dissect the neuronal circuitry and molecular mechanisms involved in the antihyperkinetic action of psychostimulants and to evaluate novel treatments for ADHD. New transgenic models mouse models targeting other genes have recently been proposed for ADHD. Here, we discuss the recent
\end{abstract}

\section{Leo $\cdot$ R. R. Gainetdinov $(\bowtie)$}

Department of Neuroscience and Brain Technologies, Istituto Italiano di Tecnologia, Via Morego 30, Genoa, Italy

e-mail: raul.gainetdinov@iit.it

D. Leo

e-mail: damiana.leo@iit.it

R. R. Gainetdinov

Skolkovo Institute of Science and Technology, 100 Novaya str., Skolkovo, Odintsovsky district, 143025, Moscow Region, Russia advances and pitfalls in modeling ADHD endophenotypes in genetically altered animals.

Keywords Attention-deficit hyperactivity disorder (ADHD) · Dopamine · Transgenic mice · Hyperactivity · Dopamine transporter $\cdot$ DAT knock-out

$\begin{array}{ll}\text { Abbreviations } \\ \text { ADHD } & \text { Attention deficit hyperactive disorder } \\ \text { DA } & \text { Dopamine } \\ \text { DAT } & \text { Dopamine transporter } \\ \text { NE } & \text { Norepinephrine } \\ \text { MPH } & \text { Methylphenidate } \\ \text { AMPH } & \text { Amphetamine }\end{array}$

\section{Introduction}

Attention deficit hyperactive disorder (ADHD) is a clinically heterogeneous disorder presenting as various combinations of impulsivity, hyperactivity and inattention symptoms. ADHD is among the most common neuropsychiatric disorders in children, affecting 5\%-7\% of children worldwide (Polanczyk et al. 2007; Faraone et al. 2003; Faraone and Mick 2010; Willcutt 2012) and often leads to adverse consequences in adult life including drug abuse, delinquency, anxiety and depression and social rejection (Barkley et al. 2004; Biederman 2005; Bernardi et al. 2012). ADHD creates a significant financial burden involving the cost of medical care and work loss for patients and family members. Causative mechanisms for ADHD have not yet been identified and at present, no objective biomarkers are available to support the diagnosis, which is based on symptom descriptions in the Diagnostic and Statistical Manual of Mental Disorders, 4th Edition (DSM-IV) (American Psychiatric Association 2000). However, a diversity of ADHD clinical forms might result in a revision of the diagnosis, classification and segregation of the distinct nosologies of ADHD in a new DSM-V edition. 
Although the exact molecular mechanisms involved in the etiology of ADHD have yet to be uncovered, clinical studies clearly indicate that ADHD has a significant genetic component (Lasky-Su et al. 2007; Faraone et al. 2005; PurperOuakil et al. 2011), most likely involving several genes with each determining the severity of particular symptoms. Environmental components that have been implicated as risk factors include brain traumas during infancy and alcohol or drug abuse during pregnancy (Sinopoli et al. 2011; Mick et al. 2002a, b; Biederman et al. 1995). Thus, genetic, developmental and environmental factors influence the severity of symptoms observed in affected individuals, leading to a "spectrum" of abnormal behaviors (Dick et al. 2010). Nevertheless, some ADHD patients present some brain abnormalities (e.g., a reduction in total brain volume; Valera et al. 2007), especially in the basal ganglia, prefrontal cortex and cerebellum (Giedd et al. 2001; Cortese and Castellanos 2012) and alterations in neural networks (Rubia et al. 2010; Konrad and Eickhoff 2010). The circuits associated with ADHD are rich in monoamines, which are involved in the mechanism of action of the psychostimulants and antidepressants used to treat this disorder. Neuropharmacological studies provide evidence that ADHD involves the dysregulation of complex interactions between the dopamine (DA), norepinephrine (NE) and 5hydroxytryptamine (serotonin) neurotransmitter systems (Pliszka 2005; Himelstein et al. 2000; Heal et al. 2009). For more than 70 years, ADHD treatment has been dominated by the use of monoaminergic psychostimulants (Bradley 1937), mostly methylphenidate (MPH) and amphetamine (AMPH), plus the catecholaminergic nonstimulant atomoxetine (ATX). These medications are generally believed to exert their therapeutic effects by increasing the availability of monoamines in the synapse by reducing their uptake rates or promoting reverse efflux as a result of interactions with monoamine transporters on the plasma membrane. Notably, not all patients respond to these treatments and both responders and nonresponders to amphetamine and methylphenidate therapy in the clinic have been documented (Heal et al. 2009; Krause et al. 2005).

The involvement of monoamines in ADHD is also supported by candidate gene association studies that show positive associations with various DA (dopamine receptor 4, DR4; dopamine receptor 5, DR5; dopamine transporter, DAT; Faraone et al. 2005; Li et al. 2006; Gizer et al. 2009; Brookes et al. 2006), NE (norepinephrine transporter, NET; Yang et al. 2004; Kim et al. 2008) and serotonergic (serotonin transporter, SERT; serotonin receptor subtype 1B gene, HTR1B; Faraone and Khan 2006) genes. However, monoamines in general act as modulators of fast neurotransmission mediated by glutamate and gamma aminobutyric acid (GABA) suggesting that many other mechanisms beyond those involved exclusively in monoaminergic transmission could be important for the pathogenesis of ADHD and the targeting of these mechanisms could provide more specific pharmacological and cognitive therapies for this disorder (Carlsson et al. 2001; Greengard 2001; Gainetdinov et al. 2001). These findings suggest that ADHD is likely to be based on several specific neurobiological dysfunctions and involves many genes, each with small effect sizes (Faraone et al. 2005).

Some specific endophenotypes of ADHD can be relatively easily modeled by targeted genetic manipulations in experimental animals, as is in the case with other neuropsychiatric disorders with a significant genetic component. An ideal model needs to recapitulate all the key endophenotypes of ADHD: inattention, impulsivity and hyperactivity. However, one single model is unlikely to be able to mimic all ADHD symptoms. At the same time, a model that recapitulates some key endophenotypes of the disorder could be useful for understanding the biological basis of the particular aspects of the disease and for predicting the clinical efficacy of potential therapeutic agents in specific clinical forms of the disorder. Thus, an ADHD animal model should mimic the fundamental behavioral characteristics of ADHD (face validity), involve a similar etiology and/or underlying pathophysiological mechanism (construct validity) and predict responses to medications that could be used in ADHD treatment with regard to behavior, molecular mechanisms and neuronal functions that have not previously been shown in clinical settings (predictive validity; Sagvolden and Johansen 2012; Gainetdinov 2010). Whereas nonhuman primate brains are closer to human brains, rodent models of ADHD have the advantage of being genetically more homogeneous, less expensive to maintain and more thoroughly characterized neurobiologically in comparison with primates (Russell et al. 2005). Thus, mouse models are invaluable tools for directly testing hypotheses on the underlying pathologies and finding new pharmacological therapies for human disorders in a relatively short period of time. Because ADHD is a heterogeneous disorder, a number of animal models have unsurprisingly been proposed that mimic symptoms of ADHD. Here, we review only transgenic rodent models with defined genetic causes that have been proposed to be useful tools for understanding ADHD neurobiology (Table 1). We do not discuss rodent models with unknown genetic origins or those that are based on environmental interventions or chemical lesions, such as the inbred spontaneously hypertensive rat (SHR), the Naples high-excitability rat (NHE), or neonatal 6-hydroxydopamine (6-OHDA) lesioned mice, which are by far the most widely studied rodent models of ADHD and subjects of a number of excellent reviews (Russell 2011; Sagvolden et al. 2009; Bari and Robbins 2011).

\section{Transgenic models: dopamine transmission-related genes}

The widespread use of rodents, especially mice, in preclinical research has been steadily growing since the 
Table 1 Mutant mice with relevance to ADHD discussed in this review

\begin{tabular}{|c|c|c|}
\hline Mutant mice & Mutation & References \\
\hline \multicolumn{3}{|c|}{ Dopamine transmission-related genes } \\
\hline$\cdot$ DAT-KO & Knock-out of dopamine transporter gene & $\begin{array}{l}\text { Giros et al. 1996; Gainetdinov and Caron } \\
\text { 2000; Trinh et al. } 2003\end{array}$ \\
\hline - DAT-KD & Knock-down of dopamine transporter gene & Zhuang et al. 2001; Tilley et al. 2007 \\
\hline • DAT-CI & Triple point-mutation in the cocaine-binding site of DAT & Napolitano et al. 2010; Tilley and Gu 2008a \\
\hline - BAC DAT-tg & Overexpression of dopamine transporter & Salahpour et al. 2008 \\
\hline$\cdot \mathrm{D} 4 \mathrm{R}-\mathrm{KO}$ & Knock-out of dopamine receptor 4 & Rubinstein et al. 1997; Helms et al. 2008 \\
\hline \multicolumn{3}{|l|}{ Other genes } \\
\hline • NK1R-KO & Knock-out of tachykinin-1 receptor & De Felipe et al. 1998; Yan et al. 2009 \\
\hline - TR $\beta \mathrm{PV}-\mathrm{KI}$ & Knock-in of human thyroid hormone $\beta$ receptor gene & Kaneshige et al. 2000; Siesser et al. 2006 \\
\hline - $39 \mathrm{X}^{\mathrm{y}} \mathrm{O}$ mice & $\begin{array}{l}\text { End-to-end fusion of the } \mathrm{X} \text { and } \mathrm{Y} \text { chromosome } \\
\text { resulting in steroid sulfatase deficiency }\end{array}$ & Davies et al. 2007, 2009 \\
\hline $\begin{array}{l}\text { - Coloboma mice/SNAP25 } \\
\text { (synaptosomal-associated } \\
\text { protein } 25 \text { ) mutant mice }\end{array}$ & $\begin{array}{l}\text { Mutation on chromosome } 2 \text { with approximately } \\
20 \text { genes disrupted including SNAP- } 25\end{array}$ & Searle 1966; Bruno et al. 2007 \\
\hline - $\mathrm{nAChR} \beta 2-\mathrm{KO}$ & $\begin{array}{l}\text { Knock-out of } \beta 2 \text {-subunit of the nicotinic } \\
\text { acetylcholine receptor }\end{array}$ & Granon et al. 2003; Granon and Changeux 2006 \\
\hline - $\mathrm{CK} 1 \delta$ mice & Over-expression of the subunit $\delta$ of casein kinase 1 & Zhou et al. 2010 \\
\hline • Git1-KO & $\begin{array}{l}\text { Knock-out of G-protein-coupled receptor } \\
\text { kinase-interacting protein-1 }\end{array}$ & Won et al. 2011; Schmalzigaug et al. 2009 \\
\hline - $\mathrm{CdK} 5-\mathrm{KO}$ & Knock-out of Cdk5-activating cofactor p35 & Drerup et al. 2010 \\
\hline • G $\beta 5-\mathrm{KO}$ & Knock-out of type $5 \mathrm{G}$ protein beta subunit & Xie et al. 2012 \\
\hline - DGK $\beta$ KO & Knock-out of diacylglycerol kinase $\beta$ & Ishisaka et al. 2012 \\
\hline
\end{tabular}

development of transgenic knock-out techniques in the 1980s (Smithies 1993) and the publication of the mouse genome in 2002 (Mouse Genome Sequencing Consortium et al. 2002). Rodents provide relatively easy targets for genome manipulation in order to create disease models by targeting candidate genes and by analyzing the related dysfunctions on a controlled genetic background. Use of the candidate ADHD gene approach in a recent meta-analysis of studies performed over the past 15 years has revealed consistent evidence of significant associations between ADHD and polymorphisms in several candidate genes, almost all of which are involved in the regulation of dopaminergic and serotonergic transmission (Gizer et al. 2009; Wu et al. 2012). The generation of knock-out, knock-in, or transgenic over-expressing animals has become a novel approach to investigating the neuronal and biochemical basis of ADHD. These transgenic mouse models representing bottom-up approaches (from gene to behavior) have provided an opportunity to link a specific gene to specific endophenotypes of the disease, thus complementing alternative top-down approaches (i.e., from behavior to the genes) based, for instance, on the selective breeding of animals demonstrating ADHD-related behavioral phenotypes of unknown origin (Russell 2011; Sagvolden et al. 2009; Bari and Robbins 2011).

Like all rodent models, transgenic mice certainly have some limitations. First, given that ADHD appears to be a complex and multifactorial disease with no reliable genetic or biochemical markers, such mouse mutants can obviously have only limited construct validity. Moreover, the deletion of certain genes might produce different phenotypes in humans and animals and transgenic animal models might not be powerful enough to mimic gene epistasis, effects of "small mutations", adaptive functional compensation and abnormal neuronal system development. Nevertheless, transgenic animals are the most reliable and simple models used to study gene-function relationships and to investigate the effects of novel pharmacological approaches.

\section{DAT knock-out mice}

Several lines of evidence suggest that abnormal DAT function is important in ADHD. Both increased and decreased DAT expression have been reported in small cohorts of ADHD patients (Sakrikar et al. 2012; Madras et al. 2005; Volkow et al. 2002) and genetic studies have demonstrated the associations of DAT gene variants with unknown functional consequences with ADHD (Spencer et al. 2012). A link between DAT function and ADHD is further suggested by the therapeutic utility of the psychostimulants methylphenidate (Ritalin) and AMPH, which exert a significant part of their action via an interaction with DAT (Sakrikar et al. 2012). Thus, several transgenic animal models of ADHD have been developed based on the postulated role of DA, particularly DAT, in this disorder. 
DAT is a member of the family of $\mathrm{Na}^{+} / \mathrm{Cl}^{-}$-dependent transporters that have the general structure of 12 transmembrane domains with intracytoplasmic carboxy- and aminoterminals (Giros and Caron 1993; Kristensen et al. 2011; Torres et al. 2003). The DAT protein is expressed selectively in DA cell bodies and terminals and can be used as a selective marker of DA neurons (Eriksen et al. 2010). In the central nervous system, DAT is mainly expressed in the striatum and nucleus accumbens, whereas in the periphery, it is present in the retina, lung, kidney and pancreas (Ciliax et al. 1995). In the striatum, DAT is exclusively presynaptic and is localized to the plasma membranes of axonal varicosities and axon terminals (Nirenberg et al. 1996). The major function of DAT is the reuptake of DA from the synaptic cleft into presynaptic nerve terminals, making DAT essential in controlling the half-life of extracellular DA. The psychostimulatory actions of MPH, cocaine and AMPH are primarily dependent on a direct interaction of these compounds with DAT, leading to attenuated DA clearance and thus elevated DA tone (Chen et al. 2006; Pifl et al. 1996; Thomsen et al. 2009; Fumagalli et al. 1998). These drugs generally exert inhibitory and/or specific reversing actions on the function of the monoamine transporters DAT, NET and SERT, thereby disrupting the normal reuptake of neurotransmitters from the synaptic cleft and causing an elevation in the extracellular monoamine levels. Although the debate continues as to whether ADHD is a hypo- or hyper-dopaminergic condition, numerous clinical genetic studies have provided evidence that alterations in DAT-mediated processes significantly contribute to the pathogenesis of ADHD (Gainetdinov 2010). DAT knockout mice (Giros et al. 1996; DAT-KO mice) have provided important information concerning the neurobiological consequences of impaired DAT function. DAT-KO mice are considered ADHD models for many reasons, including their spontaneous hyperactivity and impaired learning and memory (Gainetdinov and Caron 2000, 2001; Trinh et al. 2003). Recent studies have also demonstrated an impaired cliffavoidance reaction in DAT-KO mice, indicating increased impulsivity in these mutants (Yamashita et al. 2013). Unlike wild-type or heterozygous mice, DAT-KO mice are significantly more active in novel and home-cage environments and show remarkable deficits in learning and memory in the 8-arm maze, novel object recognition and social food preference transmission tests (Gainetdinov et al. 1999a; Wong et al. 2012). In DAT-KO animals, DA clearance is approximately 300 times slower than in controls (Gainetdinov et al. 1999b; Jones et al. 1998, 1999). However, the increase in the basal extracellular levels of DA is only approximately five-fold (two-fold in the DAT heterozygous mice), because of several compensatory mechanisms (Gainetdinov and Caron 2000, 2001; Trinh et al. 2003). Intriguingly, electrically stimulated DA release is reduced and a marked depletion of reuptake-dependent intraneuronal DA stores (20-fold) is observed in these mutants (Gainetdinov et al. 1999b; Jones et al. 1998). Thus, we can speculate that the steady-state "tonic" extracellular DA levels are increased but that "phasic" DA release might, in fact, be diminished because of depleted storage pools (Gainetdinov 2010). Importantly, the lack of DAT-mediated recycling makes DA levels in the striatum of these mice totally dependent on the rate of the ongoing synthesis of DA (Jones et al. 1998; Sotnikova et al. 2005). Notably, DAT-KO mice have disrupted DA autoreceptor function and significantly reduced tyrosine hydroxylase $(\mathrm{TH})$ protein expression, despite only minor alterations in the number of TH-positive neurons (Giros et al. 1996; Jaber et al. 1999). Indeed, unlike the normal situation in which the predominant mode of DA transmission in the striatum can be defined as a point-topoint wired transmission, this mode in DAT-KO mice can be defined as "volume transmission" in which released molecules can diffuse over longer distances in the extracellular space, thus affecting larger volumes of postsynaptic receptors and structures (Jones et al. 1998). Volume transmission is believed to occur in situations in which DAT-mediated DA reuptake is low, as in the frontal cortex or following dopaminergic degeneration in the striatum; this causes a reduction in the number of DA terminals and re-uptake sites (Zoli et al. 1999). Similar situations might occur in another commonly used model of ADHD, i.e., neonatal 6hydroxydopamine (6-OHDA)-treated rodents. In this neurotoxic ADHD model, which is used to support the hypodopaminergic theory of this disorder, the neonatal administration of the neurotoxin 6-OHDA exerts selective dopaminergic neurotoxicity by entering terminals via DAT that causes transient hyperactivity and cognitive deficits that last approximately 2 weeks in $40 \%-50 \%$ of the animals (Kostrzewa et al. 2008). Because DAT function in rodents is relatively low in the early neonatal period (Gordon et al. 1995; Patel et al. 1994), one might expect that only neurons with sufficient DAT function would be affected by 6OHDA, leaving neurons with delayed maturation of DAT intact and thus causing a transient state of low DATmediated re-uptake and "volume transmission".

As in ADHD patients, MPH and AMPH are able to reduce hyperactivity in DAT-KO animals (Gainetdinov et al. 1999a). Therefore, these mice have face and predictive validity as a model of ADHD. The "calming" effect of psychostimulants suggests the involvement of a DATindependent mechanism of action, possibly involving other monoamine transporters. The administration of inhibitors of the serotonin transporter (SERT) or of several serotonin receptor agonists and antagonists (non-selective agonists quipazine and 5-carboxamidotryptamine or the selective 5HT2A antagonist M10090) dramatically reduces the hyperactivity in DAT-KO mice (Gainetdinov et al. 1999a; Barr 
et al. 2004; Beaulieu et al. 2006) indicating an involvement of serotonergic mechanisms. At the same time, the specific NET inhibitor nisoxetine does not suppress the hyperactivity of DAT-KO animals (Gainetdinov et al. 1999a; Gainetdinov and Caron 2000) but reverses the manifestations of impulsivity in the cliff-avoidance test (Yamashita et al. 2013) and sensorimotor gating deficits in the pre-pulse inhibition test (Arime et al. 2012). The involvement of both SERT- and NET-mediated effects of psychostimulants in these models is not surprising because both SERT-KO and NET-KO mice are hypoactive (Kalueff et al. 2007; Xu et al. 2000) and, as is well established, the serotonin and NE systems closely interact at many levels, with alterations in one neurotransmitter system causing significant changes in the other (Bortolozzi and Artigas 2003).

Glutamatergic transmission might also be an intermediate in the inhibitory action of psychostimulants and serotonergic drugs on the hyperactivity of DAT-KO mice. The blockade of $\mathrm{N}$-methyl-D-aspartate (NMDA) receptors causes a remarkable potentiation of hyperactivity in DAT-KO mice and prevents the antihyperkinetic effects of psychostimulants and serotonergic drugs suggesting the involvement of cortico-striatal glutamatergic pathways in the effects of these drugs. Importantly, whereas the psychomotor stimulatory effect of psychostimulants is correlated with the well-known rise in extracellular DA levels in major DA brain areas in normal mice, psychostimulants inhibit activity without causing a decrease in elevated DA levels in DAT-KO mice. These findings give further support to the idea that, in these mutants, psychostimulants do not affect the striatal DA system directly but instead exert their antihyperkinetic effects by modulating different neurotransmitter systems in other brain regions (Gainetdinov et al. 1999a). These observations particularly highlight the processes occurring in the frontal cortex in regulating striatal mechanisms. In general, DA transmission in the striatum and frontal cortex might be differentially involved in the control of certain behaviors, with striatal mechanisms mostly contributing to the regulation of locomotor activity and cortical mechanisms regulating predominantly cognitive processes such as attention and impulsivity. Whereas extracellular DA levels in the frontal cortex of DAT-KO mice are elevated as in the striatum (Xu et al. 2009), NET is known also to contribute to the clearance of DA in this brain region. Thus, either the modulation of cortical DA dynamics via NET inhibition or the direct serotoninmediated modulation of the frontostriatal glutamatergic pathway might potently affect the aberrant behaviors caused by an enhanced striatal DA transmission in these mutants.

In summary, this mouse model shows face and predictive validity because of behavioral similarities, alterations in the catecholaminergic system and the effectiveness of psychostimulants. However, since no clear indications are yet available that the DAT level or function is altered in patients with ADHD, the construct validity of DAT-KO is only partial. Human studies on the role of DAT in ADHD etiology are still controversial, although recent brain imaging studies have shown a decrease in DAT levels in several brain areas of ADHD patients (Volkow et al. 2007, 2009a). Intriguingly, recent studies have found two novel DATcoding variants: A559V, which has been identified in two male siblings with ADHD displaying increased DAT channel activity and spontaneous non-vesicular DA release that can be greatly enhanced by membrane depolarization (MazeiRobison et al. 2008; Bowton et al. 2010) and a second rare ADHD-associated DAT-coding variant, R615C, in which amino acid substitution results in significant regulatory alterations in DAT function (Sakrikar et al. 2012).

\section{Other DAT mutant models}

Another model of mild DAT deficiency has been developed by the local injection of small interfering RNA (siRNA) against DAT into the midbrain of adult mice (Salahpour et al. 2007). However, despite a decrease of approximately $40 \%$ in DAT levels, no alterations in spontaneous locomotor activity have been found. At the same time, decreased levels of DAT have been functionally revealed by the lower level of hyperactivity induced by AMPH in siRNA-treated animals (Salahpour et al. 2007). Whereas these DAT siRNA-treated mice and DAT heterozygous mice displaying a 50\% reduction in DAT levels do not show phenotypes that are relevant to ADHD, mice with more severe DAT functional deficits, e.g., DAT knock-down mice (DAT-KD) and DAT cocaineinsensitive (DAT-CI) mice, represent useful models for understanding the role of DAT in ADHD. Hyperdopaminergic DAT-KD mice were created by reducing the expression of DAT to $10 \%$ of wild-type levels (Zhuang et al. 2001). Similar to DAT-KO mice, DAT-KD mice display a reduced rate of DA reuptake and a higher extracellular DA concentration (approximately two-fold higher than controls). DAT-KD mice display normal home cage activity but significant hyperactivity and impaired response habituation in novel environments. These mutants also demonstrate an increased motivation for food reward but do not show significant alterations in learning abilities. Notably, as in DAT-KO mice, AMPH exerts a pronounced inhibitory effect on locomotor activity in the DAT$\mathrm{KD}$ mouse; in contrast, the normal stimulatory effects of cocaine have been reported (Tilley et al. 2007).

An additional strain of DAT-deficient mice, i.e., DAT-CI (Cocaine Insensitive) mice, were obtained by introducing a triple point-mutation in the cocaine-binding site of DAT (Napolitano et al. 2010; Chen et al. 2006). In these animals, DAT is partially functional but insensitive to cocaine. Because of their significantly reduced DAT function (estimated to be in the range of $60 \%-80 \%$, based on a comparative analysis of various neurochemical parameters), DAT-CI mice exhibit 
severe alterations of DA signaling in the striatum, such as elevated extracellular DA levels, decreased total striatal DA content, enhanced DA turnover and reduced D2 dopamine receptor-mediated autoreceptor function (Napolitano et al. 2010). DAT-CI mice also lack cocaine-induced extracellular DA elevation and cocaine- and MPH-induced conditioned place preference (Tilley and $\mathrm{Gu} 2008 \mathrm{a}$, b). As might be expected, DAT-CI mutants display significant spontaneous hyperactivity (Napolitano et al. 2010). Whereas the cognitive phenotype of these mutants has not yet been characterized, not only cocaine but also several other psychostimulants, including AMPH, MPH, nomifensine and bupropion, exert antihyperkinetic action in DAT-CI mice (Napolitano et al. 2010). Similarly, a NET inhibitor has been able to induce a moderate decrease in the activity of these hyperdopaminergic mutants (Napolitano et al. 2010). Taken together, the observations of DAT-KD and DAT-CI mice support the major findings observed in DAT-KO mice. However, neither DAT-KD nor DAT-CI mice show all of the cardinal phenotypes of an ADHD mouse model, thereby displaying only partial face validity. Conversely, several attempts have been made to evaluate the effects of increased DAT expression in animal models. Although many of the DAT-deficient mice described above have phenotypes that are at least partially relevant for ADHD, the behaviors displayed by mice with increased DAT expression lack such validity. The transgenic over-expression of DAT in TH-expressing neurons by approximately $30 \%$ results in spontaneous locomotor hypoactivity in a new environment (Donovan et al. 1999). Adriani et al. (2009) have used a lentivirus to over-express or silence the DAT gene by infusing a DAT gene enhancer/silencer into the nucleus accumbens of adult Wistar rats. In the absence of general locomotor effects, DAT over-expressing rats show a somewhat increased impulsivity but they do not demonstrate a significant preference for a novel environment. The authors suggested that altered accumbal DAT function might serve a sensation-seeking phenotype and a vulnerability to impulse-control disorders. Salahpour and colleagues (2008) have generated, via the pronuclear injection of a bacterial artificial chromosome, DAT transgenic mice (DAT-tg) that significantly overexpress the transporter. In DAT-tg mice, a three-fold increase in the level of total transporter has been achieved, which results in a 50\% increase in the rate of DA uptake and a $40 \%$ decrease in DA extracellular levels. Behaviorally, these mice display normal levels of spontaneous locomotor activity but markedly increased locomotor responses to AMPH and reduced operant responses to a natural reward. These studies indicate that increased DAT expression does not recapitulate the major endophenotypes related to ADHD (no face or predictive validity), such as hyperactivity and the paradoxical inhibitory responses to AMPH (Salahpour et al. 2008). In contrast, the behavioral phenotype and the responses to psychostimulants in various strains of DAT-deficient mice generally support the clinical observations of decreased (Volkow et al. 2009b, 2007), rather than increased (Madras et al. 2005) DAT expression found in some ADHD patients, although these alterations might represent secondary adaptive changes but not causative factors of the disease. Intriguingly, DAT expression and function in normal rodents has been found to be relatively low at birth, with significant maturation of DAT occurring over an extended period of postnatal development (Gordon et al. 1995; Patel et al. 1994). If a similar developmental maturation of DAT occurs in humans, the relatively low DAT function during childhood could explain the preferential appearance of ADHD in children. Furthermore, one might expect that deficiencies in processes that are critical for DAT maturation will contribute to the etiology of this developmental disorder.

\section{D4 dopamine receptor KO mice}

Mice lacking the D1, D2, D3, D4 and D5 receptors, or some combination thereof, have been produced but all have failed to show ADHD-related phenotypes. Among all DA receptors, the most studied receptor has been D4R. Whereas alleles of the human D4R gene have repeatedly been associated with ADHD (Grady et al. 2003), D4R knock-out (D4R-KO; Rubinstein et al. 1997) mice have failed to become a valid ADHD model. These mutants demonstrate hypoactivity and have similar levels of impulsivity compared with control animals, suggesting that D4R-mediated signaling does not affect impulsivity (Helms et al. 2008). At the same time, D4R-KO mice are supersensitive to alcohol, cocaine and methamphetamine. DA synthesis and its conversion to DOPAC are elevated in the dorsal striatum of D4R-KO mice (Rubinstein et al. 1997). Taken together, these observations provide little support to consider D4R-KO mice a relevant model in ADHD research.

\section{Transgenic models: other genes}

\section{Tachykinin-1 (NK1) receptor}

The tachykinin-1 (NK1) receptor is a receptor for substance $\mathrm{P}$, which is a member of the tackyinin family of neuropeptides (Maggi 1995). Substance P levels are high in monoaminergic nuclei, especially in the substantia nigra and ventral tegmental area (Ljungdahl et al. 1978; Ribeiro-daSilva and Hökfelt 2000). Substance P preferentially activates NK1 receptors (NK1R), which are the product of the tacrl gene. Another subtype of substance P receptor, NK2, has lower binding affinity than NK1R and has only limited expression in the rat or human brain (McLean and Lowe 1994). NK1R is a member of the family of G protein-coupled receptors and is mainly expressed in subcortical regions (i.e., amygdala/hippocampus and striatum; Yan et al. 2009). When NK1R-KO animals were generated in 1998 (De Felipe et al. 
1998), the discovery of an important modulatory influence of tachykinin-1 (now known as TACR1 in humans or NK1R in rodents) on monoaminergic transmission attracted interest with regard to this factor being a novel target for antidepressants (Yan et al. 2009). In NK1R-KO mice, the serotonergic (Froger et al. 2001), norepinephrinergic (Fisher et al. 2007; Herpfer et al. 2005) and dopaminergic systems are affected (Murtra et al. 2000). The serendipitous discovery that NK1RKO mice express core features of ADHD arose from the observation that NK1R-KO mice express minor locomotor hyperactivity corrected by psychostimulants (AMPH or MPH). Moreover, hyperactivity is induced in wild-type mice by treating them with an NK1R antagonist at doses that have no effect on the behavior of NK1R-KO mice; this hyperactivity is prevented by AMPH, as occurs in NK1R-KO mice (Yan et al. 2009). These mutants also display other abnormalities that might be relevant to ADHD, such as reduced DA efflux in the frontal cortex, a lack of an increase in DA efflux in the dorsal striatum following systemic administration of AMPH and a lack of development of AMPH or morphine-induced conditioned place preference (Yan et al. 2009, 2010). NK1R$\mathrm{KO}$ mice have been reported to express inattentiveness and impulsivity in five-choice serial reaction-time task tests (5CSRTT) but AMPH does not correct these deficits (Yan et al. 2011). In a case-control study of 450 ADHD patients and 600 screened normal controls, four single-nucleotide polymorphisms at the TACR1 gene, previously known to be associated with bipolar disorder or alcoholism, were strongly associated with ADHD (Yan et al. 2010). Thus, NK1R-KO animals display some face and predictive validity as a model of ADHD and, with further validation, might become an interesting new model of the disease.

\section{Thyroid hormone receptor}

Resistance to the thyroid hormone (RTH) has long been known to be often associated with symptoms of hyperactivity (Hauser et al. 1993; Magner et al. 1986). RTH is linked to mutations in exons 9 and 10 of the human thyroid hormone $\beta$ receptor gene (TR $\beta)$. It is characterized by a normal or elevated level of the thyroid-stimulating hormone (TSH) in the presence of high levels of serum triiodothyronine (T3) and thyroxine (T4) and by the resistance of pituitary or peripheral tissues to the actions of the thyroid hormone attributable to a decreased affinity of TR $\beta$ for T3 (McDonald et al. 1998). In two studies, $50 \%-70 \%$ of RTH patients met the diagnostic criteria for ADHD (Hauser et al. 1993; Brucker-Davis et al. 1995) supporting the idea that this gene might be involved in ADHD pathogenesis. A model of knock-out mice lacking the TR $\beta$ gene was generated by Forrest and colleagues (1996). These animals had elevated TSH and free T3 and T4 but they were not hyperactive. However, male transgenic mice bearing the human
PV (the acronym for the patient name) mutant $T R \beta$ gene (RTH mutants) tested for horizontal activity displayed some hyperactivity and a moderate deficit in learning, showing normal performance after training for a reaction time task that measured sustained attention (McDonald et al. 1998). The TR $\beta$ PV knock-in (KI) mice seemed to be more promising as a model of ADHD (Kaneshige et al. 2000), as they displayed the characteristic endophenotypes of ADHD: inattention manifesting as slow reaction times and inaccuracy in an operant task, moderate hyperactivity that was not evident in a novel environment but developed gradually after repeated exposure to the environment and impulsivity observed by indirect measures (Siesser et al. 2005, 2006). TR $\beta$ PV-KI mice show increased striatal DA turnover but the response to MPH does not differ between genders or between transgenic and wild-type animals; an initial transient decrease of activity is followed by normalization up to baseline values within $1 \mathrm{~h}$ (Siesser et al. 2006). Hence, these mice seem to have some face validity as an ADHD model but limited construct validity. Ambiguous face and predictive validity (the ambiguous response to MPH) detract from the validity of this model, as demonstrated by the absence of recent reports concerning TR $\beta$ PV-KI mice utility to model ADHD.

\section{Steroid sulfatase}

Steroid sulfatase (STS) is an enzyme encoded by the Xlinked gene STS (Xp22.3) in humans and by the pseudoautosomal Sts gene in mice. It catalyzes the desulfation of steroid hormones, such as the neurosteroid dehydroepiandrosterone sulfate (DHEAS) to DHEA. DHEAS and DHEA have important effects on neuronal functions, including cognition, by acting on various neurotransmitter receptors (GABA-A, NMDA; Davies et al. 2009; Reddy 2010). Both DHEAS and its non-sulfated form DHEA are negative modulators of the GABA-A receptor and positive modulators of the NMDA receptor (Yadid et al. 2010). STS is expressed in key regions of the developing brain critical for attention and impulsivity, including the frontal cortex, thalamus and basal ganglia, i.e., regions whose structure/function is expected to be perturbed in ADHD (Stergiakouli et al. 2011). Several lines of evidence have suggested a role of STS in ADHD: males with cytogenetic deletions encompassing the gene (or with inactivating mutations within it) show an enhanced vulnerability to the disorder (Brookes et al. 2010; Kent et al. 2008). DHEA(S) levels are inversely correlated with ADHD symptomatology (Strous et al. 2001) and can be elevated by MPH treatment (Maayan et al. 2003; Lee et al. 2008). Moreover, the total or partial loss of the $\mathrm{X}$ chromosome in Turner syndrome results in attention deficits. In 1997, Davies and colleagues reported that, in $39 \mathrm{X}^{\mathrm{y}} \mathrm{O}$ mice with an end-to-end fusion of the $\mathrm{X}$ and $\mathrm{Y}$ chromosome, haploinsufficiency for STS 
accounted for attentional deficits (see Davies et al. 2009, 2007) by limiting the conversion of DHEAS to DHEA. Furthermore, DHEAS administration improved the attentional deficits in $39 \mathrm{X}^{\mathrm{y}} \mathrm{O}$ mice, suggesting that STS deletion is a possible model for the inattentive subtype of ADHD. Further characterizations of this mouse model have shown similarities with ADHD endophenotypes such as hyperactivity, heightened emotional reactivity and aggression and lowered serum DHEA levels (Trent et al. 2012a, b). The authors propose that these deficits are related to increased tissue serotonin levels in the striatum and hippocampus as a result of reduced DHEA levels (Trent et al. 2012a). The putative role of the STS gene in ADHD is also supported by the results of the pharmacological blockade of the activity of the enzyme in normal animals. This treatment produces visuo-spatial attentional deficits, perseverations, aggression and increased locomotor activity comparable with those observed in $39 \mathrm{X}^{\mathrm{y}} \mathrm{O}$ mice. Thus, $39 \mathrm{X}^{\mathrm{y}} \mathrm{O}$ mice have partial construct validity as an ADHD model and exhibit a reasonable degree of face validity. However, as with other "new" ADHD models, further investigations are needed to understand the neurobiological underpinnings of the behavioral endophenotypes caused by this mutation.

\section{Other mutant mice that are relevant for ADHD}

In 1966, a mutant mouse strain resulting from neutron irradiation, the coloboma mutant mouse, was described (Searle 1966). These mutants bear a mutation on chromosome 2 with approximately 20 genes being disrupted (e.g., PCLB-1 [phospholipase $\mathrm{c}$ beta-1] and Jag1 [Jagged 1]). Among these genes, the synaptosomal-associated protein 25 (SNAP-25), which is a key protein in synaptic vesicle docking and fusion with the presynaptic membrane, has attracted the most interest. These mice display delayed neurodevelopment and behavioral deficits that might recapitulate to some degree the developmental deficits in ADHD patients. The mice exhibit pronounced hyperactivity, impulsivity and impaired inhibition in a delayed reinforcement task (Bruno et al. 2007; Wilson 2000; Hess et al. 1994, 1996). Coloboma mice also have disrupted latent inhibition, thus indicating "inattentive" behavior (Bruno et al. 2007). The hyperkinetic behavior is corrected to a certain extent by AMPH but not at all by MPH (Hess et al. 1996; Wilson 2000) and so the mice respond only partially to classical ADHD treatments. Catecholamine metabolism is indeed altered in coloboma mice: DA release is almost completely disrupted in the dorsal striatum, whereas it is augmented in the cerebral cortex (Raber et al. 1997; Jones et al. 2001) and DA metabolite concentrations are decreased in the ventral striatum. Likewise, NE is increased in the striatum and nucleus accumbens of mutants (Jones et al. 2001). The experimental depletion of NE in this model with $N$-(2-chloroethyl)- $N$-ethyl2-bromobenzylamine hydrochloride (DSP-4) reduces hyperactivity and restores latent inhibition but does not ameliorate impulsivity (Bruno et al. 2007; Jones and Hess 2003). This has led to the idea that the hyperlocomotor activity is caused by a hyperactive norepinephrinergic system; however, the finding that hyperlocomotion is not completely abolished by NE depletion suggests that additional factors contribute to the mutant phenotype. The deletion of SNAP25 might be related to some of the behavioral deficits of these animals but SNAP25 heterozygous mice (SNAP25 homozygous KO mice are perinatally lethal) notably show no apparent phenotype (Washbourne et al. 2002). Thus, the behavioral phenotype of coloboma mice probably depends on the loss of genes other than SNAP25 within the deleted region (Jeans et al. 2007; Oliver and Davies 2009). Therefore, coloboma mice have only limited construct validity as a model of ADHD.

Among the other transgenic animals used as ADHD models, knock-out animals for the $\beta 2$-subunit of the nicotinic acetylcholine receptor are noteworthy. They display some of the key ADHD symptoms: inattention, lack of inhibitory control and hyperactivity (Granon et al. 2003; Granon and Changeux 2006). The polymorphisms of nicotinic receptor subunits in ADHD patients and the deregulation of nicotinic pathways in other ADHD models (i.e., DAT-KO mice; Weiss et al. 2007) suggest that further investigations of this model as regard to ADHD related behaviors are warranted.

Equally intriguing is the over-expression of the subunit $\delta$ of casein kinase 1 (CK1 $1 \delta$ ) in the forebrain. CK1 $1 \delta$ is highly expressed in the brain and regulates the phosphorylation of DARPP-32 (dopamine and cAMP-regulated phosphoprotein MW $32 \mathrm{kDa}$ ), which is an important, striatally expressed, protein phosphatase inhibitor that integrates synaptic inputs from DA and glutamatergic afferents. The overexpression of CK $1 \delta$ causes a decrease in DA receptor levels and mutant mice exhibit hyperactivity, reduced anxiety and nesting behavior deficiencies (Zhou et al. 2010). CK1 $\delta$ mice also show paradoxical responses to psychostimulants, displaying hypoactivity following the injection of AMPH and $\mathrm{MPH}$, indicating that $\mathrm{CK} 1$ activity has a profound effect on DA signaling in vivo. Thus, despite lacking construct validity, CK1 $1 \delta$ over-expressing mice might have some face and predictive validity as an ADHD model.

Another mouse model with partial construct validity is based on the association between the gene encoding Gprotein-coupled receptor kinase-interacting protein-1 (GIT1) and ADHD. Git1-KO mice developed by a gene trap approach show, at younger ages, a transient hyperactivity that can be inhibited by AMPH and MPH (Won et al. 2011). Furthermore, these mutants display impaired learning and memory. However, another strain of Git1-KO mice developed by homologous recombination do not demonstrate hyperactivity or altered responses to psychostimulants during adulthood (Schmalzigaug et al. 2009) or during development (R.T. Premont, personal communication). 
Recent reports have indicated that mice deficient in Cdk5-activating cofactor p35 (Drerup et al. 2010), type 5 $\mathrm{G}$ protein beta subunit $(\mathrm{G} \beta 5$; Xie et al. 2012), or diacylglycerol kinase $\beta$ (Ishisaka et al. 2012) demonstrate some phenotypes relevant to ADHD but only limited information is available on these mutants at this time. Further detailed investigations are necessary to validate their potential utility as putative models of ADHD.

\section{Concluding remarks}

The opportunity to perform targeted genetic manipulations in mice has tremendously increased our ability to evaluate the contribution of candidate genes to the pathology of ADHD. An ideal animal model of ADHD should display unambiguous construct, face and predictive validity. The major disadvantage in modeling ADHD in animals is the absence of a commonly accepted theory on its causes and pathogenesis. Thus, until the molecular mechanisms involved in the etiology and pathology of ADHD are deciphered, the construct validity of any animal model of ADHD will remain limited. Under these circumstances, the best animal models are largely based on the ability of the model to recapitulate major endophenotypes and to demonstrate the efficacy of the medications used in clinical practice. The growing understanding that ADHD represents a heterogeneous disorder, with many genetic and environmental factors contributing to it, should lead to the generation of many new animal models that might be instrumental in modeling specific ADHD endophenotypes. Thus, each single model has certain strengths and limitations that must be recognized in using the model to address specific scientific questions. Moreover, although the development of novel transgenic animal models is critically dependent on the identification of contributing genetic factors, the development of reliable approaches to investigate complex behaviors in animals is clearly also important (Markou et al. 2009). Unfortunately, such reliability is still lacking for the approaches used to study behavioral characteristics that are critical for ADHD, such as attention and impulsivity, in mice. New opportunities are emerging with the recent ability to develop transgenic rat models, for example, through zincfinger nuclease technology (Geurts et al. 2010). Rats are the preferred rodent models for cognitive research, because a well-accepted repertoire of behavioral approaches exists to assess complex behaviors such as impulsivity and attention. With increasing knowledge of the etiology and pathology of ADHD and the development of more reliable approaches to model endophenotypes of this disorder in rodents, the translational value of these studies should increase, eventually bringing a new generation of safer and more effective medications.
Open Access This article is distributed under the terms of the Creative Commons Attribution License, which permits any use, distribution and reproduction in any medium, provided the original author(s) and the source are credited.

\section{References}

Adriani W, Boyer F, Gioiosa L, Macrì S, Dreyer JL, Laviola G (2009) Increased impulsive behavior and risk proneness following lentivirus-mediated dopamine transporter over-expression in rats' nucleus accumbens. Neuroscience 159:47-58

Arime Y, Kasahara Y, Hall FS, Uhl GR, Sora I (2012) Corticosubcortical neuromodulation involved in the amelioration of prepulse inhibition deficits in dopamine transporter knockout mice. Neuropsychopharmacology 37:2522-2530

American Psychiatric Association (2000) Diagnostic and statistical manual of mental disorders (DSMIV-TR), 4th edn. American Psychiatric Association, Arlington

Bari A, Robbins TW (2011) Animal models of ADHD. Curr Top Behav Neurosci 7:149-185

Barkley RA, Fischer M, Smallish L, Fletcher K (2004) Young adult follow-up of hyperactive children: antisocial activities and drug use. J Child Psychol Psychiatry 45:195-211

Barr AM, Lehmann-Masten V, Paulus M, Gainetdinov RR, Caron MG, Geyer MA (2004) The selective serotonin-2A receptor antagonist M100907 reverses behavioral deficits in dopamine transporter knockout mice. Neuropsychopharmacology 29:221-228

Beaulieu J-M, Sotnikova TD, Gainetdinov RR, Caron MG (2006) Paradoxical striatal cellular signaling responses to psychostimulants in hyperactive mice. J Biol Chem 281:32072-32080

Bernardi S, Faraone SV, Cortese S, Kerridge BT, Pallanti S, Wang S, Blanco C (2012) The lifetime impact of attention deficit hyperactivity disorder: results from the National Epidemiologic Survey on Alcohol and Related Conditions (NESARC). Psychol Med $42: 875-887$

Biederman J (2005) Attention-deficit/hyperactivity disorder: a selective overview. Biol Psychiatry 57:1215-1220

Biederman J, Milberger S, Faraone SV, Kiely K, Guite J, Mick E, Ablon S, Warburton R, Reed E (1995) Family-environment risk factors for attention-deficit hyperactivity disorder. A test of Rutter's indicators of adversity. Arch Gen Psychiatry 52:464-470

Bortolozzi A, Artigas F (2003) Control of 5-hydroxytryptamine release in the dorsal raphe nucleus by the noradrenergic system in rat brain. Role of alpha-adrenoceptors. Neuropsychopharmacology 28:421-434

Bowton E, Saunders C, Erreger K, Sakrikar D, Matthies HJ, Sen N, Jessen T, Colbran RJ, Caron MG, Javitch JA, Blakely RD, Galli A (2010) Dysregulation of dopamine transporters via dopamine D2 autoreceptors triggers anomalous dopamine efflux associated with attention-deficit hyperactivity disorder. J Neurosci 30:6048-6057

Bradley C (1937) The behavior of children receiving benzedrine. Am J Psychiatry 94:577-585

Brookes KJ, Mill J, Guindalini C, Curran S, Xu X, Knight J, Chen CK, Huang YS, Sethna V, Taylor E, Chen W, Breen G, Asherson P (2006) A common haplotype of the dopamine transporter gene associated with attention-deficit/hyperactivity disorder and interacting with maternal use of alcohol during pregnancy. Arch Gen Psychiatry 63:74-81

Brookes KJ, Hawi Z, Park J, Scott S, Gill M, Kent L (2010) Polymorphisms of the steroid sulfatase (STS) gene are associated with attention deficit hyperactivity disorder and influence brain tissue mRNA expression. Am J Med Genet B Neuropsychiatr Genet 153B:1417-1424 
Brucker-Davis F, Skarulis MC, Grace MB, Benichou J, Hauser P, Wiggs E, Weintraub BD (1995) Genetic and clinical features of 42 kindreds with resistance to thyroid hormone. The National Institutes of Health Prospective Study. Ann Intern Med 123:572-583

Bruno KJ, Freet CS, Twining RC, Egami K, Grigson PS, Hess EJ (2007) Abnormal latent inhibition and impulsivity in coloboma mice, a model of ADHD. Neurobiol Dis 25:206-216

Carlsson A, Waters N, Holm-Waters S, Tedroff J, Nilsson M, Carlsson ML (2001) Interactions between monoamines, glutamate, and GABA in schizophrenia: new evidence. Annu Rev Pharmacol Toxicol 41:237-260

Chen R, Tilley MR, Wei H, Zhou F, Zhou FM, Ching S, Quan N, Stephens RL, Hill ER, Nottoli T, Han DD, Gu HH (2006) Abolished cocaine reward in mice with a cocaine-insensitive dopamine transporter. Proc Natl Acad Sci USA 103:9333-9338

Ciliax BJ, Heilman C, Demchyshyn LL, Pristupa ZB, Ince E, Hersch SM, Niznik HB, Levey AI (1995) The dopamine transporter: immunochemical characterization and localization in brain. $\mathrm{J}$ Neurosci 15:1714-1723

Cortese S, Castellanos FX (2012) Neuroimaging of attention-deficit/ hyperactivity disorder: current neuroscience-informed perspectives for clinicians. Curr Psychiatry Rep 14:568-578

Davies W, Humby T, Isles AR, Burgoyne PS, Wilkinson LS (2007) Xmonosomy effects on visuospatial attention in mice: a candidate gene and implications for Turner syndrome and attention deficit hyperactivity disorder. Biol Psychiatry 61:1351-1360

Davies W, Humby T, Kong W, Otter T, Burgoyne PS, Wilkinson LS (2009) Converging pharmacological and genetic evidence indicates a role for steroid sulfatase in attention. Biol Psychiatry 66:360-367

De Felipe C, Herrero JF, O'Brien JA, Palmer JA, Doyle CA, Smith AJ, Laird JM, Belmonte C, Cervero F, Hunt SP (1998) Altered nociception, analgesia and aggression in mice lacking the receptor for substance P. Nature 392:394-397

Dick DM, Riley B, Kendler KS (2010) Nature and nurture in neuropsychiatric genetics: where do we stand? Dialogues Clin Neurosci 12:7-23

Donovan DM, Miner LL, Perry MP, Revay RS, Sharpe LG, Przedborski S, Kostic V, Philpot RM, Kirstein CL, Rothman RB, Schindler CW, Uhl GR (1999) Cocaine reward and MPTP toxicity: alteration by regional variant dopamine transporter overexpression. Brain Res Mol Brain Res 73:37-49

Drerup JM, Hayashi K, Cui H, Mettlach GL, Long MA, Marvin M, Sun X, Goldberg MS, Lutter M, Bibb JA (2010) Attention-deficit/ hyperactivity phenotype in mice lacking the cyclin-dependent kinase 5 cofactor p35. Biol Psychiatry 68:1163-1171

Eriksen J, Jørgensen TN, Gether U (2010) Regulation of dopamine transporter function by protein-protein interactions: new discoveries and methodological challenges. J Neurochem 113:27-41

Faraone SV, Khan SA (2006) Candidate gene studies of attention-deficit/ hyperactivity disorder. J Clin Psychiatry 67(Suppl 8):13-20

Faraone SV, Mick E (2010) Molecular genetics of attention deficit hyperactivity disorder. Psychiatr Clin North Am 33:159-180

Faraone SV, Sergeant J, Gillberg C, Biederman J (2003) The worldwide prevalence of ADHD: is it an American condition? World Psychiatry 2:104-113

Faraone SV, Perlis RH, Doyle AE, Smoller JW, Goralnick JJ, Holmgren MA, Sklar P (2005) Molecular genetics of attentiondeficit/hyperactivity disorder. Biol Psychiatry 57:1313-1323

Fisher AS, Stewart RJ, Yan T, Hunt SP, Stanford SC (2007) Disruption of noradrenergic transmission and the behavioural response to a novel environment in NK1R-/- mice. Eur J Neurosci 25:11951204

Forrest D, Hanebuth E, Smeyne RJ, Everds N, Stewart CL, Wehner JM, Curran T (1996) Recessive resistance to thyroid hormone in mice lacking thyroid hormone receptor beta: evidence for tissuespecific modulation of receptor function. EMBO J 15:3006-3015
Froger N, Gardier AM, Moratalla R, Alberti I, Lena I, Boni C, De Felipe C, Rupniak NM, Hunt SP, Jacquot C, Hamon M, Lanfumey L (2001) 5-Hydroxytryptamine (5-HT)1A autoreceptor adaptive changes in substance $\mathrm{P}$ (neurokinin 1) receptor knockout mice mimic antidepressant-induced desensitization. J Neurosci 21:8188-8197

Fumagalli F, Gainetdinov RR, Valenzano KJ, Caron MG (1998) Role of dopamine transporter in methamphetamine-induced neurotoxicity: evidence from mice lacking the transporter. J Neurosci 18:4861-4869

Gainetdinov RR (2010) Strengths and limitations of genetic models of ADHD. Atten Defic Hyperact Disord 2:21-30

Gainetdinov RR, Caron MG (2000) An animal model of attention deficit hyperactivity disorder. Mol Med Today 6:43-44

Gainetdinov RR, Caron MG (2001) Genetics of childhood disorders: XXIV. ADHD, part 8: hyperdopaminergic mice as an animal model of ADHD. J Am Acad Child Adolesc Psychiatry 40:380-382

Gainetdinov RR, Wetsel WC, Jones SR, Levin ED, Jaber M, Caron MG (1999a) Role of serotonin in the paradoxical calming effect of psychostimulants on hyperactivity. Science 283:397-401

Gainetdinov RR, Jones SR, Caron MG (1999b) Functional hyperdopaminergia in dopamine transporter knock-out mice. Biol Psychiatry 46:303-311

Gainetdinov RR, Mohn AR, Bohn LM, Caron MG (2001) Glutamatergic modulation of hyperactivity in mice lacking the dopamine transporter. Proc Natl Acad Sci USA 98:11047-11054

Geurts AM, Cost GJ, Rémy S, Cui X, Tesson L, Usal C, Ménoret S, Jacob HJ, Anegon I, Buelow R (2010) Generation of genespecific mutated rats using zinc-finger nucleases. Methods Mol Biol 597:211-225

Giedd JN, Blumenthal J, Molloy E, Castellanos FX (2001) Brain imaging of attention deficit/hyperactivity disorder. Ann N Y Acad Sci 931:33-49

Giros B, Caron MG (1993) Molecular characterization of the dopamine transporter. Trends Pharmacol Sci 14:43-49

Giros B, Jaber M, Jones SR, Wightman RM, Caron MG (1996) Hyperlocomotion and indifference to cocaine and amphetamine in mice lacking the dopamine transporter. Nature 379:606-612

Gizer IR, Ficks C, Waldman ID (2009) Candidate gene studies of ADHD: a meta-analytic review. Hum Genet 126:51-90

Gordon I, Weizman R, Rosenne E, Rehavi M (1995) Developmental and age-related alterations in rat brain presynaptic dopaminergic mechanisms. Brain Res Dev Brain Res 85:225-228

Grady DL, Chi HC, Ding YC, Smith M, Wang E, Schuck S, Flodman P, Spence MA, Swanson JM, Moyzis RK (2003) High prevalence of rare dopamine receptor $\mathrm{D} 4$ alleles in children diagnosed with attention-deficit hyperactivity disorder. Mol Psychiatry 8:536-545

Granon S, Changeux J-P (2006) Attention-deficit/hyperactivity disorder: a plausible mouse model? Acta Paediatr 95:645-649

Granon S, Faure P, Changeux J-P (2003) Executive and social behaviors under nicotinic receptor regulation. Proc Natl Acad Sci USA 100:9596-9601

Greengard P (2001) The neurobiology of dopamine signaling. Biosci Rep 21:247-269

Hauser P, Zametkin AJ, Martinez P, Vitiello B, Matochik JA, Mixson AJ, Weintraub BD (1993) Attention deficit-hyperactivity disorder in people with generalized resistance to thyroid hormone. N Engl J Med 328:997-1001

Heal DJ, Cheetham SC, Smith SL (2009) The neuropharmacology of ADHD drugs in vivo: insights on efficacy and safety. Neuropharmacology 57:608-618

Helms CM, Gubner NR, Wilhelm CJ, Mitchell SH, Grandy DK (2008) D4 receptor deficiency in mice has limited effects on impulsivity and novelty seeking. Pharmacol Biochem Behav 90:387-393

Herpfer I, Hunt SP, Stanford SC (2005) A comparison of neurokinin 1 receptor knock-out (NK1-/-) and wildtype mice: exploratory behaviour and extracellular noradrenaline concentration in the 
cerebral cortex of anaesthetised subjects. Neuropharmacology 48:706-719

Hess EJ, Collins KA, Copeland NG, Jenkins NA, Wilson MC (1994) Deletion map of the coloboma $(\mathrm{Cm})$ locus on mouse chromosome 2. Genomics 21:257-261

Hess EJ, Collins KA, Wilson MC (1996) Mouse model of hyperkinesis implicates SNAP-25 in behavioral regulation. J Neurosci 16:3104-3111

Himelstein J, Newcorn JH, Halperin JM (2000) The neurobiology of attention-deficit hyperactivity disorder. Front Biosci 5:D461D478

Ishisaka M, Kakefuda K, Oyagi A, Ono Y, Tsuruma K, Shimazawa M, Kitaichi K, Hara H (2012) Diacylglycerol kinase $\beta$ knockout mice exhibit attention-deficit behavior and an abnormal response on methylphenidate-induced hyperactivity. PLoS One 7:e37058

Jaber M, Dumartin B, Sagné C, Haycock JW, Roubert C, Giros B, Bloch B, Caron MG (1999) Differential regulation of tyrosine hydroxylase in the basal ganglia of mice lacking the dopamine transporter. Eur J Neurosci 11:3499-3511

Jeans AF, Oliver PL, Johnson R, Capogna M, Vikman J, Molnár Z, Babbs A, Partridge CJ, Salehi A, Bengtsson M, Eliasson L, Rorsman P, Davies KE (2007) A dominant mutation in Snap25 causes impaired vesicle trafficking, sensorimotor gating, and ataxia in the blinddrunk mouse. Proc Natl Acad Sci USA 104:2431-2436

Jones MD, Hess EJ (2003) Norepinephrine regulates locomotor hyperactivity in the mouse mutant coloboma. Pharmacol Biochem Behav 75:209-216

Jones MD, Williams ME, Hess EJ (2001) Abnormal presynaptic catecholamine regulation in a hyperactive SNAP-25-deficient mouse mutant. Pharmacol Biochem Behav 68:669-676

Jones SR, Gainetdinov RR, Jaber M, Giros B, Wightman RM, Caron MG (1998) Profound neuronal plasticity in response to inactivation of the dopamine transporter. Proc Natl Acad Sci USA 95:4029-4034

Jones SR, Gainetdinov RR, Caron MG (1999) Application of microdialysis and voltammetry to assess dopamine functions in genetically altered mice: correlation with locomotor activity. Psychopharmacology (Berl) 147:30-32

Kalueff AV, Fox MA, Gallagher PS, Murphy DL (2007) Hypolocomotion, anxiety and serotonin syndrome-like behavior contribute to the complex phenotype of serotonin transporter knockout mice. Genes Brain Behav 6:389-400

Kaneshige M, Kaneshige K, Zhu X, Dace A, Garrett L, Carter TA, Kazlauskaite R, Pankratz DG, Wynshaw-Boris A, Refetoff S, Weintraub B, Willingham MC, Barlow C, Cheng S (2000) Mice with a targeted mutation in the thyroid hormone beta receptor gene exhibit impaired growth and resistance to thyroid hormone. Proc Natl Acad Sci USA 97:13209-13214

Kent L, Emerton J, Bhadravathi V, Weisblatt E, Pasco G, Willatt LR, McMahon R, Yates JR (2008) X-linked ichthyosis (steroid sulfatase deficiency) is associated with increased risk of attention deficit hyperactivity disorder, autism and social communication deficits. J Med Genet 45:519-524

Kim C-H, Waldman ID, Blakely RD, Kim K-S (2008) Functional gene variation in the human norepinephrine transporter: association with attention deficit hyperactivity disorder. Ann N Y Acad Sci 1129:256-260

Konrad K, Eickhoff SB (2010) Is the ADHD brain wired differently? A review on structural and functional connectivity in attention deficit hyperactivity disorder. Hum Brain Mapp 31:904-916

Kostrzewa RM, Kostrzewa JP, Brown RW, Nowak P, Brus R (2008) Dopamine receptor supersensitivity: development, mechanisms, presentation, and clinical applicability. Neurotox Res 14:121-128

Krause J, La Fougere C, Krause K-H, Ackenheil M, Dresel SH (2005) Influence of striatal dopamine transporter availability on the response to methylphenidate in adult patients with ADHD. Eur Arch Psychiatry Clin Neurosci 255:428-431

Kristensen AS, Andersen J, Jørgensen TN, Sørensen L, Eriksen J, Loland CJ, Strømgaard K, Gether U (2011) SLC6 neurotransmitter transporters: structure, function, and regulation. Pharmacol Rev 63:585-640

Lasky-Su J, Banaschewski T, Buitelaar J, Franke B, Brookes K, Sonuga-Barke E, Ebstein R, Eisenberg J, Gill M, Manor I, Miranda A, Mulas F, Oades RD, Roeyers H, Rothenberger A, Sergeant J, Steinhausen HC, Taylor E, Zhou K, Thompson M, Asherson P, Faraone SV (2007) Partial replication of a DRD4 association in ADHD individuals using a statistically derived quantitative trait for ADHD in a family-based association test. Biol Psychiatry 62:985-990

Lee MS, Yang JW, Ko YH, Han C, Kim SH, Lee MS, Joe SH, Jung IK (2008) Effects of methylphenidate and bupropion on DHEA-S and cortisol plasma levels in attention-deficit hyperactivity disorder. Child Psychiatry Hum Dev 39:201-209

Li D, Sham PC, Owen MJ, He L (2006) Meta-analysis shows significant association between dopamine system genes and attention deficit hyperactivity disorder (ADHD). Hum Mol Genet 15:22762284

Ljungdahl A, Hökfelt T, Nilsson G, Goldstein M (1978) Distribution of substance P-like immunoreactivity in the central nervous system of the rat-II. Light microscopic localization in relation to catecholamine-containing neurons. Neuroscience 3:945-976

Maayan R, Yoran-Hegesh R, Strous R, Nechmad A, Averbuch E, Weizman A, Spivak B (2003) Three-month treatment course of methylphenidate increases plasma levels of dehydroepiandrosterone (DHEA) and dehydroepiandrosterone-sulfate (DHEA-S) in attention deficit hyperactivity disorder. Neuropsychobiology 48:111-115

Madras BK, Miller GM, Fischman AJ (2005) The dopamine transporter and attention-deficit/hyperactivity disorder. Biol Psychiatry 57:1397-1409

Maggi CA (1995) The mammalian tachykinin receptors. Gen Pharmacol 26:911-944

Magner JA, Petrick P, Menezes-Ferreira MM, Stelling M, Weintraub BD (1986) Familial generalized resistance to thyroid hormones: report of three kindreds and correlation of patterns of affected tissues with the binding of [125I] triiodothyronine to fibroblast nuclei. J Endocrinol Invest 9:459-470

Markou A, Chiamulera C, Geyer MA, Tricklebank M, Steckler T (2009) Removing obstacles in neuroscience drug discovery: the future path for animal models. Neuropsychopharmacology 34:74-89

Mazei-Robison MS, Bowton E, Holy M, Schmudermaier M, Freissmuth M, Sitte HH, Galli A, Blakely RD (2008) Anomalous dopamine release associated with a human dopamine transporter coding variant. J Neurosci 28:7040-7046

McDonald MP, Wong R, Goldstein G, Weintraub B, Cheng SY, Crawley JN (1998) Hyperactivity and learning deficits in transgenic mice bearing a human mutant thyroid hormone betal receptor gene. Learn Mem 5:289-301

McLean S, Lowe III JA (1994) Agonist and antagonist receptor binding. In: Buck SH (ed) The tachykinin receptors.Humana, Totowa, N.J., pp 67-99

Mick E, Biederman J, Faraone SV, Sayer J, Kleinman S (2002a) Casecontrol study of attention-deficit hyperactivity disorder and maternal smoking, alcohol use, and drug use during pregnancy. J Am Acad Child Adolesc Psychiatry 41:378-385

Mick E, Biederman J, Prince J, Fischer MJ, Faraone SV (2002b) Impact of low birth weight on attention-deficit hyperactivity disorder. J Dev Behav Pediatr 23:16-22

Mouse Genome Sequencing Consortium, Waterston RH, Lindblad-Toh K, Birney E, Rogers J, Abril JF et al (2002) Initial sequencing and comparative analysis of the mouse genome. Nature 420:520-562 
Murtra P, Sheasby AM, Hunt SP, De Felipe C (2000) Rewarding effects of opiates are absent in mice lacking the receptor for substance P. Nature 405:180-183

Napolitano F, Bonito-Oliva A, Federici M, Carta M, Errico F, Magara S, Martella G, Nisticò R, Centonze D, Pisani A, Gu HH, Mercuri NB, Usiello A (2010) Role of aberrant striatal dopamine D1 receptor/cAMP/protein kinase A/DARPP32 signaling in the paradoxical calming effect of amphetamine. J Neurosci 30:1104311056

Nirenberg MJ, Vaughan RA, Uhl GR, Kuhar MJ, Pickel VM (1996) The dopamine transporter is localized to dendritic and axonal plasma membranes of nigrostriatal dopaminergic neurons. J Neurosci 16:436-447

Oliver PL, Davies KE (2009) Interaction between environmental and genetic factors modulates schizophrenic endophenotypes in the Snap-25 mouse mutant blind-drunk. Hum Mol Genet 18:45764589

Patel AP, Cerruti C, Vaughan RA, Kuhar MJ (1994) Developmentally regulated glycosylation of dopamine transporter. Brain Res Dev Brain Res 83:53-58

Pifl C, Giros B, Caron MG (1996) The dopamine transporter. The cloned target site of Parkinsonism-inducing toxins and of drugs of abuse. Adv Neurol 69:235-238

Pliszka SR (2005) The neuropsychopharmacology of attention-deficit/ hyperactivity disorder. Biol Psychiatry 57:1385-1390

Polanczyk G, De Lima MS, Horta BL, Biederman J, Rohde LA (2007) The worldwide prevalence of ADHD: a systematic review and metaregression analysis. Am J Psychiatry 164:942-948

Purper-Ouakil D, Ramoz N, Lepagnol-Bestel A-M, Gorwood P, Simonneau M (2011) Neurobiology of attention deficit/hyperactivity disorder. Pediatr Res 69:69R-76R

Raber J, Mehta PP, Kreifeldt M, Parsons LH, Weiss F, Bloom FE, Wilson MC (1997) Coloboma hyperactive mutant mice exhibit regional and transmitter-specific deficits in neurotransmission. $\mathrm{J}$ Neurochem 68:176-186

Reddy DS (2010) Neurosteroids: endogenous role in the human brain and therapeutic potentials. Prog Brain Res 186:113-137

Ribeiro-da-Silva A, Hökfelt T (2000) Neuroanatomical localisation of Substance $\mathrm{P}$ in the CNS and sensory neurons. Neuropeptides $34: 256-271$

Rubia K, Cubillo A, Smith AB, Woolley J, Heyman I, Brammer MJ (2010) Disorder-specific dysfunction in right inferior prefrontal cortex during two inhibition tasks in boys with attention-deficit hyperactivity disorder compared to boys with obsessivecompulsive disorder. Hum Brain Mapp 31:287-299

Rubinstein M, Phillips TJ, Bunzow JR, Falzone TL, Dziewczapolski G, Zhang G, Fang Y, Larson JL, McDougall JA, Chester JA, Saez C, Pugsley TA, Gershanik O, Low MJ, Grandy DK (1997) Mice lacking dopamine D4 receptors are supersensitive to ethanol, cocaine, and methamphetamine. Cell 90:991-1001

Russell VA (2011) Overview of animal models of attention deficit hyperactivity disorder (ADHD). Curr Protoc Neurosci 9:Unit9.35

Russell VA, Sagvolden T, Johansen EB (2005) Animal models of attention-deficit hyperactivity disorder. Behav Brain Funct 1:9

Sagvolden T, Johansen EB (2012) Rat models of ADHD. Curr Top Behav Neurosci 9:301-315

Sagvolden T, Johansen EB, Wøien G, Walaas SI, Storm-Mathisen J, Bergersen LH, Hvalby O, Jensen V, Aase H, Russell VA, Killeen PR, Dasbanerjee T, Middleton FA, Faraone SV (2009) The spontaneously hypertensive rat model of ADHD - the importance of selecting the appropriate reference strain. Neuropharmacology 57:619-626

Sakrikar D, Mazei-Robison MS, Mergy MA, Richtand NW, Han Q, Hamilton PJ, Bowton E, Galli A, Veenstra-Vanderweele J, Gill M, Blakely RD (2012) Attention deficit/hyperactivity disorderderived coding variation in the dopamine transporter disrupts microdomain targeting and trafficking regulation. $\mathrm{J}$ Neurosci 32:5385-5397

Salahpour A, Medvedev IO, Beaulieu J-M, Gainetdinov RR, Caron MG (2007) Local knockdown of genes in the brain using small interfering RNA: a phenotypic comparison with knockout animals. Biol Psychiatry 61:65-69

Salahpour A, Ramsey AJ, Medvedev IO, Kile B, Sotnikova TD, Holmstrand E, Ghisi V, Nicholls PJ, Wong L, Murphy K, Sesack SR, Wightman RM, Gainetdinov RR, Caron MG (2008) Increased amphetamine-induced hyperactivity and reward in mice overexpressing the dopamine transporter. Proc Natl Acad Sci USA 105:4405-4410

Schmalzigaug R, Rodriguiz RM, Bonner PE, Davidson CE, Wetsel WC, Premont RT (2009) Impaired fear response in mice lacking GIT1. Neurosci Lett 458:79-83

Searle AG (1966) New mutants. II. Coloboma. Mouse News Lett $35: 27$

Siesser WB, Cheng S, McDonald MP (2005) Hyperactivity, impaired learning on a vigilance task, and a differential response to methylphenidate in the TRbetaPV knock-in mouse. Psychopharmacology (Berl) 181:653-663

Siesser WB, Zhao J, Miller LR, Cheng S-Y, McDonald MP (2006) Transgenic mice expressing a human mutant betal thyroid receptor are hyperactive, impulsive, and inattentive. Genes Brain Behav 5:282-297

Sinopoli KJ, Schachar R, Dennis M (2011) Traumatic brain injury and secondary attention-deficit/hyperactivity disorder in children and adolescents: the effect of reward on inhibitory control. J Clin Exp Neuropsychol 33:805-819

Smithies O (1993) Animal models of human genetic diseases. Trends Genet 9:112-116

Sotnikova TD, Beaulieu JM, Barak LS, Wetsel WC, Caron MG, Gainetdinov RR (2005) Dopamine-independent locomotor actions of amphetamines in a novel acute mouse model of Parkinson disease. PLoS Biol 3:e271

Spencer TJ, Biederman J, Faraone SV, Madras BK, Bonab AA, Dougherty DD, Batchelder H, Clarke A, Fischman AJ (2012) Functional genomics of attention-deficit/hyperactivity disorder (ADHD) risk alleles on dopamine transporter binding in ADHD and healthy control subjects. Biol Psychiatry. doi:10.1016/ j.biopsych.2012.11.010

Stergiakouli E, Langley K, Williams H, Walters J, Williams NM, Suren S, Giegling I, Wilkinson LS, Owen MJ, O'Donovan MC, Rujescu D, Thapar A, Davies W (2011) Steroid sulfatase is a potential modifier of cognition in attention deficit hyperactivity disorder. Genes Brain Behav 10:334-344

Strous RD, Spivak B, Yoran-Hegesh R, Maayan R, Averbuch E, Kotler M, Mester R, Weizman A (2001) Analysis of neurosteroid levels in attention deficit hyperactivity disorder. Int J Neuropsychopharmacol 4:259-264

Thomsen M, Han DD, Gu HH, Caine SB (2009) Lack of cocaine selfadministration in mice expressing a cocaine-insensitive dopamine transporter. J Pharmacol Exp Ther 331:204-211

Tilley MR, Gu HH (2008a) The effects of methylphenidate on knockin mice with a methylphenidate-resistant dopamine transporter. J Pharmacol Exp Ther 327:554-560

Tilley MR, Gu HH (2008b) Dopamine transporter inhibition is required for cocaine-induced stereotypy. Neuroreport 19:1137-1140

Tilley MR, Cagniard B, Zhuang X, Han DD, Tiao N, Gu HH (2007) Cocaine reward and locomotion stimulation in mice with reduced dopamine transporter expression. BMC Neurosci 8:42

Torres GE, Gainetdinov RR, Caron MG (2003) Plasma membrane monoamine transporters: structure, regulation and function. Nat Rev Neurosci 4:13-25

Trent S, Cassano T, Bedse G, Ojarikre OA, Humby T, Davies W (2012a) Altered serotonergic function may partially account for 
behavioral endophenotypes in steroid sulfatase-deficient mice. Neuropsychopharmacology 37:1267-1274

Trent S, Dennehy A, Richardson H, Ojarikre OA, Burgoyne PS, Humby T, Davies W (2012b) Steroid sulfatase-deficient mice exhibit endophenotypes relevant to attention deficit hyperactivity disorder. Psychoneuroendocrinology 37:221-229

Trinh JV, Nehrenberg DL, Jacobsen JPR, Caron MG, Wetsel WC (2003) Differential psychostimulant-induced activation of neural circuits in dopamine transporter knockout and wild type mice. Neuroscience 118:297-310

Valera EM, Faraone SV, Murray KE, Seidman LJ (2007) Meta-analysis of structural imaging findings in attention-deficit/hyperactivity disorder. Biol Psychiatry 61:1361-1369

Volkow ND, Fowler JS, Wang G, Ding Y, Gatley SJ (2002) Mechanism of action of methylphenidate: insights from PET imaging studies. J Atten Disord 6 (Suppl 1):S31-S43

Volkow ND, Wang GJ, Newcorn J, Fowler JS, Telang F, Solanto MV, Logan J, Wong C, Ma Y, Swanson JM, Schulz K, Pradhan K (2007) Brain dopamine transporter levels in treatment and drug naive adults with ADHD. Neuroimage 34:1182-1190

Volkow ND, Wang GJ, Kollins SH, Wigal TL, Newcorn JH, Telang F, Fowler JS, Zhu W, Logan J, Ma Y, Pradhan K, Wong C, Swanson JM (2009a) Evaluating dopamine reward pathway in ADHD: clinical implications. JAMA 302:1084-1091

Volkow ND, Fowler JS, Logan J, Alexoff D, Zhu W, Telang F, Wang GJ, Jayne M, Hooker JM, Wong C, Hubbard B, Carter P, Warner D, King P, Shea C, Xu Y, Muench L, Apelskog-Torres K (2009b) Effects of modafinil on dopamine and dopamine transporters in the male human brain: clinical implications. JAMA 301:1148-1154

Washbourne P, Thompson PM, Carta M, Costa ET, Mathews JR, Lopez-Benditó G, Molnár Z, Becher MW, Valenzuela CF, Partridge LD, Wilson MC (2002) Genetic ablation of the tSNARE SNAP-25 distinguishes mechanisms of neuroexocytosis. Nat Neurosci 5:19-26

Weiss S, Tzavara ET, Davis RJ, Nomikos GG, Michael McIntosh J, Giros B, Martres MP (2007) Functional alterations of nicotinic neurotransmission in dopamine transporter knock-out mice. Neuropharmacology 52:1496-1508

Willcutt EG (2012) The prevalence of DSM-IV attention-deficit/hyperactivity disorder: a meta-analytic review. Neurotherapeutics 9:490-499

Wilson MC (2000) Coloboma mouse mutant as an animal model of hyperkinesis and attention deficit hyperactivity disorder. Neurosci Biobehav Rev 24:51-57

Won H, Mah W, Kim E, Kim JW, Hahm EK, Kim MH, Cho S, Kim J, Jang H, Cho SC, Kim BN, Shin MS, Seo J, Jeong J, Choi SY, Kim D, Kang C, Kim E (2011) GIT1 is associated with ADHD in humans and ADHD-like behaviors in mice. Nat Med 17:566-572

Wong P, Chang CC, Marx CE, Caron MG, Wetsel WC, Zhang X (2012) Pregnenolone rescues schizophrenia-like behavior in dopamine transporter knockout mice. PLoS One 7:e51455
Wu J, Xiao H, Sun H, Zou L, Zhu L-Q (2012) Role of dopamine receptors in ADHD: a systematic meta-analysis. Mol Neurobiol 45:605-620

Xie K, Ge S, Collins VE, Haynes CL, Renner KJ, Meisel RL, Lujan R, Martemyanov KA (2012) Gß5-RGS complexes are gatekeepers of hyperactivity involved in control of multiple neurotransmitter systems. Psychopharmacology (Berl) 219:823-834

Xu F, Gainetdinov RR, Wetsel WC, Jones SR, Bohn LM, Miller GW, Wang YM, Caron MG (2000) Mice lacking the norepinephrine transporter are supersensitive to psychostimulants. Nat Neurosci 3:465-471

Xu TX, Sotnikova TD, Liang C, Zhang J, Jung JU, Spealman RD, Gainetdinov RR, Yao WD (2009) Hyperdopaminergic tone erodes prefrontal long-term potential via a D2 receptor-operated protein phosphatase gate. J Neurosci 29:14086-14099

Yadid G, Sudai E, Maayan R, Gispan I, Weizman A (2010) The role of dehydroepiandrosterone (DHEA) in drug-seeking behavior. Neurosci Biobehav Rev 35:303-314

Yamashita M, Sakakibara Y, Hall FS, Numachi Y, Yoshida S, Kobayashi H, Uchiumi O, Uhl GR, Kasahara Y, Sora I (2013) Impaired cliff avoidance reaction in dopamine transporter knockout mice. Psychopharmacology (Berl). doi:10.1007/s00213-0133009-9

Yan TC, Hunt SP, Stanford SC (2009) Behavioural and neurochemical abnormalities in mice lacking functional tachykinin-1 (NK1) receptors: a model of attention deficit hyperactivity disorder. Neuropharmacology 57:627-635

Yan TC, McQuillin A, Thapar A, Asherson P, Hunt SP, Stanford SC, Gurling H (2010) NK1 (TACR1) receptor gene "knockout" mouse phenotype predicts genetic association with ADHD. J Psychopharmacol 24:27-38

Yan TC, Dudley JA, Weir RK, Grabowska EM, Peña-Oliver Y, Ripley TL, Hunt SP, Stephens DN, Stanford SC (2011) Performance deficits of NK1 receptor knockout mice in the 5-choice serial reaction-time task: effects of d-amphetamine, stress and time of day. PLoS One 6:e17586

Yang L, Wang Y-F, Li J, Faraone SV (2004) Association of norepinephrine transporter gene with methylphenidate response. J Am Acad Child Adolesc Psychiatry 43:1154-1158

Zhou M, Rebholz H, Brocia C, Warner-Schmidt JL, Fienberg AA, Nairn AC, Greengard P, Flajolet M (2010) Forebrain overexpression of CK1delta leads to down-regulation of dopamine receptors and altered locomotor activity reminiscent of ADHD. Proc Natl Acad Sci USA 107:4401-4406

Zhuang X, Oosting RS, Jones SR, Gainetdinov RR, Miller GW, Caron MG, Hen R (2001) Hyperactivity and impaired response habituation in hyperdopaminergic mice. Proc Natl Acad Sci USA 98:1982-1987

Zoli M, Jansson A, Syková E, Agnati LF, Fuxe K (1999) Volume transmission in the CNS and its relevance for neuropsychopharmacology. Trends Pharmacol Sci 20:142-150 